\title{
Selection of Tomato Hybrids With Zingiberene Concentration for Breeding Programs to Pest Resistance
}

\author{
Maria Elisa de Sena Fernandes ${ }^{1}$, Flávio Lemes Fernandes ${ }^{2}$, Natalia Oliveira Silva ${ }^{1}$, Derly José Henriques da Silva ${ }^{3}$, \\ Frederico Garcia Pinto ${ }^{4}$ \& Rodrigo Soares Ramos ${ }^{5}$ \\ ${ }^{1}$ Laboratório de Pesquisa em Horticultura, Universidade Federal de Viçosa - Campus de Rio Paranaíba, Minas \\ Gerais, Brazil \\ ${ }^{2}$ Laboratório de Manejo de Pragas, Universidade Federal de Viçosa - Campus de Rio Paranaíba, Minas Gerais, \\ Brazil \\ ${ }^{3}$ Departamento de Fitotecnia , Universidade Federal de Viçosa - Campus Viçosa, Minas Gerais, Brazil \\ ${ }^{4}$ Laboratório de Análises Químicas, Universidade Federal de Viçosa - Campus de Rio Paranaíba, Minas Gerais, \\ Brazil \\ ${ }^{5}$ Laboratório de Entomologia, Universidade Federal de Viçosa - Campus Viçosa, Minas Gerais, Brazil \\ Correspondence: Maria Elisa de Sena Fernandes, Universidade Federal de Viçosa - Campus de Rio Paranaíba, \\ Rodovia MG-230 Km 7 - CEP: 38810-000, Rio Paranaíba. Tel: 34-3855-9308/9343. E-mail:maria.sena@ufv.br
}

\author{
Received: April 3, 2014 Accepted: April 17, 2014 Online Published: May 15, 2014 \\ doi:10.5539/jas.v6n6p148 URL: http://dx.doi.org/10.5539/jas.v6n6p148
}

\begin{abstract}
The zingiberene is a sesquiterpene that is present in tomato leaves. This compound is known to promote resistance to pests and diseases. The Brazil has a germplasm bank of vegetable at Universidade Federal de Viçosa (HGB-UFV) crops with over 8 million accesses. One technique that helps in the choice of progenitors with favorable concentrations of zingiberene is the diallel crosses. The diallel crosses allow the estimation of general combining ability (GCA) and specific combining ability (SCA). Thus, the aim of this study was to find out tomato hybrids with high zingiberene concentrations. The genitors were divided into two contrasting groups for resistance to pests. The characterization and quantification spectrophotometric of zingiberene was performed, obtaining absorbance values at $270 \mathrm{~nm}$. To determine the content of zingiberene in hybrids those were coming from the diallel cross. The analysis from the spectrophotometric method was performed. The estimates of GCA and SCA of these hybrids at combinations HGB 2119 x LA716, HGB 2119 x PI 12786, HGB 2214 x HGB 674, HGB 2064 x HGB 674, HGB 2214 x PI 127826, HGB 985 x LA 716 and Santa Clara x HGB 674 have high potential in tomato plant breeding aiming of resistance to pests and diseases.
\end{abstract}

Keywords: tomato, diallel crosses, spectrophotometric

\section{Introduction}

The tomato plants (Solanum lycopersicum Mill.) is one of the vegetables grown worldwide (Filgueira, 2008). Among the main factors affecting the production of tomato, are pests and diseases, so the search for resistant cultivars is necessary.The attainment of cultivars resistant to pests and diseases is of fundamental importance to study the causes of resistance. Among the causes of resistance, has been to highlight the secondary metabolites that can be stored within cells, epidermal glands or trichomes of plants (Panda \& Khush, 1995). Thus, one of the outstanding secondary metabolites in tomato is zingiberene which is a sesquiterpene that is present in leaflets of Solanum habrochaites var. hirsutum (Gianfagna, Carter, \& Sacalis, 1992). The effect of this metabolite has been reported in some arthropod pests of tomato as Tetranychus urticae (Acari: Tetranychidae), T. evansi (Acari: Tetranychidae), Spodoptera exigua (Lepidoptera: Noctuidae), Tuta absoluta (Lepidoptera: Gelechiidae), Bemisia tabaci (Hemiptera: Aleyrodidae), among others (Freitas et al., 1998; Weston, Johnson, Burton, \& Snyder, 1989; Campos, 1999; Eigenbrode, Trumble, Millar, \& White, 1994; Azevedo et al., 1999; Freitas, 1999).

The study of the variation of zingiberene concentrations in tomato hybrids can be estimated using breeding tools known as diallel crosses, among them partial diallel which is a statistical genetic design where many genitors are crossed pairs, and allow to estimate the general combining ability (GCA) and specific combining ability (SCA). Using these estimates are selected the best genitors and the best hybrids for use in breeding programs (Ramalho, 
Santos, \& Zimmermann, 1993; Cruz \& Regazzi, 2001; Pádua et al., 2010). Thus, the aim of this study was to select tomato hybrids with zingiberene concentrations favorable to breeding programs.

\section{Materials and Methods}

\subsection{General Characteristics}

The tomato experiments were conducted at the Universidade Federal de Viçosa, Campus Rio Paranaíba, Brazil. Eleven tomato accessions that were crossed in a partial diallel mating scheme were used (Table 1). In group I, the cultivar ' Santa Clara ' (S. lycopersicum L.) produces oblong fruits with two or three loculus for fresh consumption. The access BGH -985 (S. lycopersicum L.) the fruits show red external color and rounded shape. The access BGH -2119 (S. lycopersicum L.) the fruit has slightly flattened shape and soluble solids content about $3.76^{\circ}$ Brix. The access BGH -2214 (S. lycopersicum L.) has soluble solids content about $3.57^{\circ}$ Brix. The access BGH 2064 (S. lycopersicum L.) has red external color when the fruit is ripe. Meanwhile, the group II was composed by access BGH-1497 (S. lycopersicum L.) rounded, slightly flattened fruits and red coloring. In addition, the access BGH-4309 (S. lycopersicum L.) has red color and resistance to T. absoluta and the access BGH-674 (S. lycopersicum L.) also has red color and resistance to T. absoluta. The access LA 716 (Solanum pennellii $=L$. pennellii) has the ester acylsugar, whileaccess PI127826 (Solanum habrochaites $=$ Lycopersicon hirsutum var. hirsutum) produces zingiberene and the access PI 134417 (S. habrochaites $=$ L. hirsutum var. glabratum ) produces tridecanone (Silva et al, 2009; www.ufv.br/bgh).

Table 1. Scheme of diallel resulting of crossing between five genitors from group I and six genitors from group II

\begin{tabular}{lllllll}
\hline Group I/Group II & 1-HGB 1497 & 2-HGB 4309 & 3-HGB 674 & 4-LA 716 & 5-PI 127826 & 6-PI 134417 \\
\hline 1-985 & $\mathrm{Y}_{11}$ & $\mathrm{Y}_{12}$ & $\mathrm{Y}_{13}$ & $\mathrm{Y}_{14}$ & $\mathrm{Y}_{15}$ & $\mathrm{Y}_{16}$ \\
2-2064 & $\mathrm{Y}_{21}$ & $\mathrm{Y}_{22}$ & $\mathrm{Y}_{23}$ & $\mathrm{Y}_{24}$ & $\mathrm{Y}_{25}$ & $\mathrm{Y}_{26}$ \\
3-2214 & $\mathrm{Y}_{31}$ & $\mathrm{Y}_{32}$ & $\mathrm{Y}_{33}$ & $\mathrm{Y}_{34}$ & $\mathrm{Y}_{35}$ & $\mathrm{Y}_{36}$ \\
4-2119 & $\mathrm{Y}_{41}$ & $\mathrm{Y}_{42}$ & $\mathrm{Y}_{43}$ & $\mathrm{Y}_{44}$ & $\mathrm{Y}_{45}$ & $\mathrm{Y}_{46}$ \\
5-'Santa Clara' & $\mathrm{Y}_{51}$ & $\mathrm{Y}_{52}$ & $\mathrm{Y}_{53}$ & $\mathrm{Y}_{54}$ & $\mathrm{Y}_{55}$ & $\mathrm{Y}_{56}$ \\
\hline
\end{tabular}

The genitors were divided into two contrasting groups for resistance to pests. The first group was composed of five tomato accessions with desirable agronomic traits and the second group with six tomato accessions with traits of resistance to pests (Leite, Picanço, Guedes, \& Gusmão, 1998; Marim et al., 2004; Resende et al., 2008; Oliveira et al., 2009; Antônio, Silva, Picanço, Santos, \& Fernandes, 2011).

The sowing of hybrids was performed in polystyrene trays $(68 \mathrm{~cm} \times 34 \mathrm{~cm})$ of 128 cells (BP 128/60). The substrate used was burnt pine bark plus vermiculite (Bioplant ${ }^{\circledR}$ ). In each cell were added three to four tomato seeds. The seedlings were grown in a greenhouse (temperature $25 \pm 5^{\circ} \mathrm{C}$ and relative humidity of $75 \%$ ) until 35 days after germination when they were transplanted to plastic pots $5 \mathrm{~L}$ containing slope bank + cattle manure $(2: 1)$ with six expanded leaves. The pots were spaced $60 \times 60 \mathrm{~cm}$ in a greenhouse. The fertilization of plants, as well as cultural practices was performed according to Fontes and Silva (2005).

\subsection{Quantification of Zingiberene}

Spectrophotometric quantitation of zingiberene was performed, obtaining absorbance values at $270 \mathrm{~nm}$. To determine the content of zingiberene in hybrids that were from the diallel cross, the analysis of the spectrophotometric method proposed by Freitas, Maluf, Cardoso \& Benites (2000) was performed. Six leaf discs from the young leaves expanded of the upper third of plants were removed, a total of $4.21 \mathrm{~cm}^{2}$ of leaf area. Three replicates were collected for each treatment. The leaflets were placed in test tubes identified according to the treatment. After collecting the material was added $2 \mathrm{~mL}$ of hexane to each tube, then homogenizing it in a tube shaker (model AP56 Phoenix ${ }^{\circledR}$ vortex-type) for 40 seconds, to promote the extraction of zingiberene. After stirring, the leaf disks were removed and the extracts were subjected to reading absorbance at UV-visible spectrophotometer device (Evolution 300, Thermo Scientific) at a wavelength of $270 \mathrm{~nm}$ (Silverstein, Bassler, \& Morrill, 1994; Maluf, Campos, \& Cardoso, 2001). 


\subsection{Statistical Analysis}

The data of concentrations were submitted to Cochran and Lilliefors tests to verify if the data obeyed presuppositions of homogeneity variance and error normality (Cochran, 1947; Eisenhart, 1947). Subsequently, these data were subjected to variance analysis and the means were compared by the Scott Knott test $(p<0.05)$.

The mean of parental lines and $\mathrm{F}_{1}$ 's plants were analyzed according to the partial diallel model proposed by Geraldi and Miranda Filho (1988), adapted from proposed model by Griffing (1956). Statistical procedures were carried out using the program Genes (Cruz, 2006).

\section{Results}

Detect significant differences between the concentrations of zingiberene $\left(\mathrm{F}_{(30,62)}=13.94, \mathrm{p}<0.0001\right)$, hybrids with higher concentrations were HGB 2064 x HGB1497, SC x HGB 674, averaging $1.34 \pm 0.22$ and $2.61 \pm 0.05$ respectively (Table 2).

We detected a significant difference $(\mathrm{p}<0.05)$ the effects of general combining ability of the genitors in group I $\left(\right.$ GCA I) $\left(\mathrm{F}_{(4,62)}=12.43, \mathrm{p}<0.001\right)$, group II $(\mathrm{GCA}$ II $)\left(\mathrm{F}_{(5,62)}=11.30, \mathrm{p}<0.001\right)$ and specific combining ability to the character of zingiberene (SCA I x II) $\left(\mathrm{F}_{(20,62)}=15.58, \mathrm{p}<0.001\right)$. For the content of zingiberene the highest value was observed in group I stood out the cultivar 'Santa Clara' and the group II access PI 127826 stood out among the other accesses (Table 3). It was detected that for the concentration of zingiberene combining outstanding among the other was 'Santa Clara' x HGB 674 (Table 4).

Table 2. Average \pm standard error of zingiberene absorbance at $270 \mathrm{~nm}$ in the cultivar 'Santa Clara' and (F1) 30 tomato hybrids

\begin{tabular}{cc}
\hline Treatments & Zingibereno $(\mathrm{nm})^{\top}$ \\
\hline HGB 2064 x HGB 1497 & $1.34 \pm 0.22 \mathrm{a}$ \\
HGB 2064 x HGB 4309 & $0.88 \pm 0.16 \mathrm{c}$ \\
HGB 2064 x HGB 674 & $0.81 \pm 0.05 \mathrm{c}$ \\
HGB 2064 x LA 716 & $1.01 \pm 0.06 \mathrm{c}$ \\
HGB 2064 x PI 127826 & $1.42 \pm 0.17 \mathrm{~b}$ \\
HGB 2064 x PI 134417 & $1.42 \pm 0.24 \mathrm{~b}$ \\
HGB 2119 x HGB 1497 & $0.01 \pm 0.00 \mathrm{e}$ \\
HGB 2119 X HGB 4309 & $1.40 \pm 0.28 \mathrm{~b}$ \\
HGB 2119 x HGB 674 & $0.96 \pm 0.11 \mathrm{c}$ \\
HGB 2119 x LA 716 & $1.18 \pm 0.30 \mathrm{~b}$ \\
HGB 2119 x PI 127826 & $1.16 \pm 0.14 \mathrm{~b}$ \\
HGB 2119 x PI 134417 & $0.05 \pm 0.00 \mathrm{e}$ \\
HGB 2214 x HGB 1497 & $0.71 \pm 0.12 \mathrm{c}$ \\
HGB 2214 x HGB 4309 & $0.43 \pm 0.01 \mathrm{~d}$ \\
HGB 2214 x HGB 674 & $0.42 \pm 0.02 \mathrm{~d}$ \\
HGB 2214 x LA 716 & $1.21 \pm 0.08 \mathrm{~b}$ \\
HGB 2214 x PI 127826 & $0.81 \pm 0.02 \mathrm{c}$ \\
HGB 2214 x PI 134417 & $0.69 \pm 0.09 \mathrm{c}$ \\
HGB 985 x HGB 1497 & $0.97 \pm 0.11 \mathrm{c}$ \\
HGB 985 x HGB 4309 & $0.03 \pm 0.00 \mathrm{e}$ \\
HGB 985 x HGB 674 & $1.51 \pm 0.53 \mathrm{~b}$ \\
HGB 985 x LA716 & $1.19 \pm 0.08 \mathrm{~b}$ \\
BG 985 x PI 127826 & $0.92 \pm 0.07 \mathrm{c}$ \\
HGB 985 x PI 134417 & $0.04 \pm 0.00 \mathrm{e}$ \\
SC x HGB 1497 & $1.47 \pm 0.13 \mathrm{~b}$ \\
SC x HGB 4309 & $1.36 \pm 0.19 \mathrm{~b}$ \\
SC x HGB 674 & $2.61 \pm 0.05 \mathrm{a}$ \\
SC x LA 716 & $0.02 \pm 0.00 \mathrm{e}$ \\
SC x PI 127826 & $0.80 \pm 0.17 \mathrm{c}$ \\
SC x PI 134417 & $0.72 \pm 0.01 \mathrm{c}$ \\
'Santa Clara' & $0.15 \pm 0.03 \mathrm{e}$ \\
\hline
\end{tabular}

${ }^{1}$ Means followed by the same letter in the column belong to the same group by Scott-Knott test at $\mathrm{p}<0.05$. 
Table 3. Estimates (Z) of the GCA effects of genitors Group I (GCA I) and II (GCA II) for zingiberene in the tested accessions

\begin{tabular}{cccc}
\hline Group I & GCA I $(Z)$ & Group II & GCA II (Z) \\
\hline HGB 985 & 0.23 & HGB 1497 & -0.01 \\
HGB 2064 & -0.13 & HGB 4309 & -0.09 \\
HGB 2214 & -0.20 & HGB 674 & 0.34 \\
HGB 2119 & -0.14 & LA 716 & 0.00 \\
'Santa Clara' & 0.24 & PI 127826 & 0.34 \\
\hline
\end{tabular}

$\mathrm{GCA}=$ General Combining Ability.

Table 4. Estimates (Z) of the SCA effects among progenitors of groups I and II for the content zingiberene between tomato hybrids

\begin{tabular}{cccc}
\hline Treatments & $\mathbf{Z}$ & Treatments & $\mathbf{Z}$ \\
\hline HGB 2064 x HGB 1497 & 0.20 & HGB 2214 x LA 716 & 0.49 \\
HGB 2064 x HGB 4309 & -0.16 & HGB 2214 x PI 127826 & -0.01 \\
HGB 2064 x HGB 674 & -0.68 & HGB 2214 x PI 134417 & 0.32 \\
HGB 2064 x LA 716 & -0.14 & HGB 985 x HGB 1497 & 0.22 \\
HGB 2064 x PI 127826 & 0.16 & HGB 985 x HGB4309 & -0.66 \\
HGB 2064 x PI 134417 & 0.62 & HGB 985 x HGB 674 & 0.39 \\
HGB 2119 x HGB 1497 & -0.76 & HGB 985 x LA 716 & 0.42 \\
HGB 2119 x HGB 4309 & 0.71 & HGB 985 x PI 127826 & 0.04 \\
HGB 2119x HGB 674 & -0.17 & HGB 985 x PI 134417 & -0.41 \\
HGB 2119 x LA 716 & 0.39 & SC x HGB 1497 & 0.32 \\
HGB 2119 x PI 127826 & 0.26 & SC x HGB 4309 & 0.29 \\
HGB 2119 x PI 134417 & -0.43 & SC x HGB 674 & 1.10 \\
HGB 2214 x HGB 1497 & 0.01 & SC x LA 716 & -1.16 \\
HGB 2214 x HGB 4309 & -0.18 & SC x PI 127826 & -0.46 \\
HGB 2214 x HGB 674 & -0.64 & SC x PI 134417 & -0.09 \\
\hline
\end{tabular}

\section{Discussion}

It was observed that the variation of hybrids resulted in differentiation in zingiberene concentrations between treatments. This significance indicates the existence of genetic variability among the tested genitors, a fact of importance in determining the estimates of the genetic control of these traits. Considering this, there are many studies reporting the effect of zingiberene on oviposition, preference and even the survival of arthropod pests (Ecole, Picanço, Moreira, \& Magalhães, 2000; Maluf et al., 2001; Azevedo, Faria, Maluf, Oliveira, \& Freitas, 2003; Gonçalves et al., 2006; Silva et al., 2009).

Estimates of general combining ability (GCA) and specific combining ability (SCA) was significant for the content of zingiberene. The significance for the GCA and SCA indicates the existence of variability among GCA effects associated with additive genetic effects, and between SCA effects, associated with the non-additive. Another important factor that should be noted is the magnitude of the sums of squares of GCA and SCA.

Considering the magnitudes and signs of the estimates of general combining ability, the HGB 985, 2064, 2214, 2119 and "Santa Clara" accessions belonging to the group I they are the genitors most recommended to be included in tomato breeding programs aimed at increasing resistance to T. absoluta. With reference to the genitors of the group II, PI 127826, HGB 674 and LA 716 accessions are the most recommended programs aiming to improve resistance to pests, these accessions were chosen therefore have negative contributions. Thus, 
according to Cruz and Regazzi (1997) and Cruz, Regazzi and Carneiro (2004), the effect of the GCA is an indicator of the superiority of the genitor and its relative divergence among the rest.

Regarding the estimates of SCA, Cruz and Vencovsky (1989) reported that these values, the additive-dominant models correspond to the extent of genetic divergence between a genitor and others present in diallel (Griffing, 1956; Cruz \& Regazzi, 1994; Bastos et al., 2003).

Thus, based on estimates of general and specific combining ability of these hybrids at the combinations HGB 2119 x LA 716, HGB 2119 x PI 12786, HGB 2214 x HGB 674, HGB 2064 x HGB 674, HGB 2214 x PI 127826, HGB 985 x LA 716 and Santa Clara x HGB 674 have high potential in tomato breeding aimed at resistance to pests, for having at least one genitor with high GCA and SCA. Among the pests has been highlighted for $T$. urticae, T. evansi, S. exigua and T. absoluta (Freitas et al., 1998; Eigenbrode, Trumble, Millar, \& White, 1994; Azevedo et al., 1999; Freitas, 1999).

\section{Conclusion}

We conclude that the HGB 2119 x LA 716, BH 2119 x PI 127826, HGB 2214 x PI 127826, HGB 985 x LA 716 and SC x HGB 674 showed higher trocar levels por concentrations of zingiberene and higher estimates of GCA and SCA and these are potential hybrids for use in tomato breeding programs.

\section{Acknowledgements}

Financial support from the Brazilian government agencies Conselho Nacional de Desenvolvimento Científico e Tecnológico (CNPq), Fundação de Amparo à Pesquisa do Estado de Minas Gerais (FAPEMIG) and Coordenação de Aperfeiçoamento de Pessoal de Nível Superior (CAPES) is acknowledged.

\section{References}

Antônio, A. C., Silva, D. J. H., Picanço, M. C., Santos, N. T., \& Fernandes, M. E. S. (2011). Tomato plant inheritance of antixenotic resistance to tomato leafminer. Pesquisa Agropecuária Brasileira, 46, 74-80. http://dx.doi.org/10.1590/S0100-204X2011000100010

Azevedo, S. M., Faria, M. V., Maluf, W. R., Oliveira, A. C. B., \& Freitas, J. A. (2003). Zingiberene-mediated resistance to the South American tomato pinworm derived from Lycopersicon hirsutum var. hirsutum. Euphytica, 134, 347-351. http://dx.doi.org/10.1023/B:EUPH.0000005007.14924.d2

Azevedo, S. M., Maluf, W. R., Faria, M. V., Oliveira, A. C. B., Ribeiro, C. A., Gonçalves-Gervásio, R. C., \& Santa-Cecília, L. V. C. (1999). Resistência à traça (Tuta absoluta) em genótipos de tomateiro com diferentes teores de sesquiterpenos nos folíolos. In: Congresso Brasileiro de Olericultura, 39, 1999, Tubarão. Resumo... Tubarão: Sociedade Brasileira de Olericultura.

Campos, G. A. (1999). Inter-relações entre teor de zingibereno, tipos de tricomas foliares e resistência a ácaros Tetranychus evansi em tomateiro. Lavras. (Master's Thesis in Crop Science) - Universidade Federal de Lavras.

Cochran, W. G. (1947). Some consequences when the assumptions for the analysis of variance are not satisfied. Biometrics, 3, 22-38. http://dx.doi.org/10.2307/3001535

Cruz, C. D. (2006). Programa Genes - Biometria. Viçosa: UFV. 382p.

Cruz, C. D., \& Regazzi, A. J. (1994). Modelos biométricos aplicados ao melhoramento genético. Viçosa: Universidade Federal de Viçosa.

Cruz, C. D., \& Regazzi, A. J. (1997). Modelos biométricos aplicados ao melhoramento genético. Viçosa: UFV. 1997.

Cruz, C. D., \& Regazzi, A. J. (2001). Modelos biométricos aplicados ao melhoramento genético. Viçosa: UFV.

Cruz, C. D., \& Vencovsky, R. (1989). Comparação de alguns métodos de análise dialélica. Revista Brasileira de Genética, 12, 425-438.

Cruz, C. D., Regazzi, A. J., \& Carneiro, P. C. S. (2004). Modelos biométricos aplicados ao melhoramento genético. Viçosa, MG: UFV.

Ecole, C. C., Picanço, M. C., Moreira, M. D., \& Magalhães, S. T. V. (2000). Componentes químicos associados à resistência de Lycopersicon hirsutum f. typicum a Tuta absoluta (Meyrick) (Lepidoptera: Gelechiidae). Anais da Sociedade Entomológica do Brasil, 29, 327-337. http://dx.doi.org/10.1590/S0301-8059200000 0200015 
Eigenbrode, S. D., Trumble, J. T., Millar, J. G., \& White, K. K. (1994). Topical toxicity of tomato sesquiterpenes to the armyworm and the role of these compounds in resistance derived from accession of Lycopersicon hirsutum f. typicum. Journal of Agricultural and Food Chemistry, 42, 807-810. http://dx.doi.org/ $10.1021 / \mathrm{jf00039a042}$

Eisenhart, C. (1947). The assumptions underlying the analysis of variance. Biometrics, 3, 1-21. http://dx.doi.org/10.2307/3001534

Filgueira, F. A. R. (2008). Novo manual de olericultura: agrotecnologia moderna na produção e comercialização de hortaliças (3th ed., pp. 194-241). Viçosa, MG: Ed. UFV.

Fontes, P. C. R., \& Silva, D. J. H. (2005). Cultura do tomate. In P. C. R. Fontes (Ed.). Olericultura teoria e prática (pp. 457-475). Suprema Grafia e Editora. Cultura do tomate.

Freitas, J. A. (1999). Resistência genética de tomateiro Lycopersicon sp. à mosca branca Bemisia spp. mediada por zingibereno contido em tricomas glandulares. Lavras. (Doctoral Thesis in Plant Breeding) Universidade Federal de Lavras.

Freitas, J. A., Cardoso, M. G., Maluf, W. R., Santos, C. D., Nelson, D. L., Costa, J. T., ... Spada, L. (1998). Identificação do sesquiterpeno zingibereno, aleloquímico responsável pela resistência à Tuta absoluta (Meyrick, 1917) na cultura do tomateiro. Ciência \& Agrotecnologia, 22(4), 483-489.

Freitas, J. A., Maluf, W. R., Cardoso, M. G., \& Benites, F. R. G. (2000). Métodos para quantificação do zingibereno em tomateiro, visando à seleção indireta de plantas resistentes aos artrópodes praga. Acta Scientiarum, 22, 943-949.

Geraldi, I. O., \& Miranda-Filho, J. B. (1988). Adapted models for the analysis of combining ability of varieties in partial diallel crosses. Brazilian Journal of Genetics, 11, 419-430.

Gianfana, T. J., Carter, C. D., \& Sacalis, J. N. (1992). Temperature and photoperiod influence trichome density and sesquiterpene contento of Lycopersicum hirsutum f. hirsutum. Plant Physiology, 100, 1403-1405. http://dx.doi.org/10.1104/pp.100.3.1403

Gonçalves, L. D., Maluf, W. R., Cardoso, M. G., Resende, J. T. V., Castro, E. M., Santos, N. M., ... Faria, M. V. (2006). Relação entre zingibereno, tricomas foliares e repelência de tomateiros a Tetranychus evansi. Pesquisa Agropecuária Brasileira, 41, 267-273. http://dx.doi.org/10.1590/S0100-204 X2006000200011

Griffing, B. (1956). Concept of general and specific combining ability in relation to diallel crossing systems. Australiann Journal of Biological Science, 9, 463-463.

Leite, G. L. D., Picanço, M. C., Guedes, R. N. C., \& Gusmão, M. R. (1998). Selectivity of insecticides with and without mineral oil to Brachygastra lecheguana (Hymenoptera: Vespidae): a predator of Tuta absoluta (Lepidoptera: Gelechiidae). Ceiba, 39, 3-6.

Maluf, W. R., Campos, G. A., \& Cardoso, M. G. (2001). Relationships between trichome types and spider mite (Tetranychus evansi) repellence in tomatoes with respect to foliar zingiberene contents. Euphytica, 121, 73-80. http://dx.doi.org/10.1023/A:1012067505361

Marim, B. G., Juhász, A. C. P., Silva, D. J. H., Mattedi, A. P., Soares, B. O., Guimarães, M. A., \& Abreu, F. B. (2004). Divergência genética de acessos de tomateiro do banco de germoplasma de hortaliças da UFV em relação a fatores de perdas em frutos, Congresso Brasileiro de Olericultura.

Oliveira, F., Dasilva, D., Leite, G., Jham, G., Picanco, M. C., \& Silva, D. J. H. (2009). Resistance of 57 greenhouse-grown accessions of Lycopersicon esculentum and three cultivars to Tuta absoluta (Meyrick) (Lepidoptera: Gelechiidae). Scientia Horticulturae, 119, 182-187. http://dx.doi.org/10.1016/j.scienta.2008. 07.012

Pádua, T. R. P., Gomes, L. A. A., Maluf, W. R., Carvalho Filho, J. L. S., Gonçalves Neto, Á. C., \& Andrade, M. C. (2010). Capacidade combinatória de híbridos de tomateiro de crescimento determinado, resistentes a Begomovirus e Tospovirus. Pesquisa Agropecuária Brasileira, 45, 818-825. http://dx.doi.org/10.1590 /S0100-204X 2010000800007

Panda, N., \& Krush, G. S. (1995). Host plant resistance to pest. Guildford: Biddles.

Ramalho, M. A. P., Santos, J. B., \& Zimmermann, M. J. O. (1993). Genética quantitativa em plantas autógamas: aplicações ao melhoramento do feijoeiro. Goiânia: UFG. 
Resende, J. T. V., Maluf, W. R., Cardoso, M. G., Faria, M. V., Goncalves, L. D., \& Nascimento, I. R. (2008). Resistance of tomato genotypes with high level of acylsugars to Tetranychus evansi. Baker \& Pritchard. Scientia Agricola, 65, 31-35. http://dx.doi.org/10.1590/S0103-90162008000100005

Silva, V. F., Maluf, W. R., Cardoso, M. G., Neto, Á. C. G., Maciel, G. M.; Nízio, D. A. C., \& Silva,V. A. (2009). Resistência mediada por aleloquímicos de genótipos de tomateiro à mosca-branca e ao ácaro-rajado. Pesquisa Agropecuária Brasileira, 44(9), 1262-1269. http://dx.doi.org/10.1590/S0100-204X200900100 0008

Silverstein, R. M., Bassler, G. C., \& Morrill, T. C. (1994). Identificação espectrométrica de compostos orgânicos. 5a ed. Rio de Janeiro.

Weston, P. A., Johnson, D. A., Burton, H. T., \& Snyder, J. C. (1989). Trichome secretion composition, trichome densities, and spider mite resistance of tem accessions of Lycopersicon hirsutum. Journal of the American Society for Horticultural Science, 114(3), 492-498.

\section{Copyrights}

Copyright for this article is retained by the author(s), with first publication rights granted to the journal.

This is an open-access article distributed under the terms and conditions of the Creative Commons Attribution license (http://creativecommons.org/licenses/by/3.0/). 